\title{
Maternal Thyroid Hormones Trajectories and Neonatal Behavioral Disorders
}

\author{
Ahmed R.G* \\ Division of Anatomy and Embryology, Zoology Department, Faculty of Science, Beni-Suef University, Beni- \\ Suef, Egypt
}

*Corresponding Author: Ahmed R.G, Division of Anatomy and Embryology, Zoology Department, Faculty of Science, Beni-Suef University, Beni-Suef, Egypt, Email: ahmedragab08@ gmail.com

\section{COMMENTARY}

The normal adequate of the maternal thyroid hormones (THs) (El-bakry et al., 2010; Ahmed, 2011, 2012a,b, 2013, 2014, 2015a-c, 2016a-d, 2017a-t; Ahmed et al., 2008, 2010, 2012, 2013a,b, 2014; 2015a,b; Ahmed and Ahmed, 2012; Ahmed and Incerpi, 2013; Van Hercket al., 2013; Ahmed and El-Gareib, 2014,Incerpi et al., 2014; Candelotti et al., 2015; De Vito et al., 2015; El-Ghareeb et al., 2016; Ahmed and ElGareib, 2017; Endendijk et al., 2017; Gigena et al., 2017) is necessary for the fetal/neonatal brain development (Henrichs et al., 2013). During the normal gestation, the level of thyrotropin (TSH) was increased and the level of free thyroxine (FT4) was correspondingly decreased (Stricker et al., 2007; Ahmed et al., 2008). These alterations are within the normal range and may be predictive of neonatal development (Pop et al., 1995, 1999 \&2003; Ahmed et al., 2008). However, mothers with problems in the THs before and during pregnancy had neonates with the lowest mental and motor development scores (Pop et al., 1995, 1999 \&2003; Endendijk et al., 2017). In addition, it seems that mild increases in TSH might delay the fetal brain development and consequent attention disorders or problems, specifically in boys (Glinoer et al., 1993; Endendijk et al., 2017).

Several studies reported that the disturbance in the thyroid functions during the gestation (maternal hypothyroxinemia; low FT4 and normal TSH levels) can cause neonatal cognitive disorders such as depression or anxiety (internalizing problems), and several cognitive problems such as aggression, attention problems or hyperactivity (externalizing problems) (Brownlie et al., 2004; Hagberg et al.,
2010; Henrichs et al., 2010; Van Mil et al., 2012; Bornstein et al., 2013; Henrichs et al., 2013; Endendijk et al., 2017). In addition, these disorders can extend to delay the language pronunciation (Henrichs et al., 2010) and impair the executive functioning (Van Mil et al., 2012; Endendijk et al., 2017). In human, the maternal thyroid dysfunction (hypothyroxinemia, higher TSH and thyroid-peroxidase antibody (TPO) levels) can stimulate several externalizing problems in their infants (Ghassabian et al., 2011, 2012 \& 2014). On the other hand, the connections between the maternal THs, neonatal cognitive development and child sex type are almost unidentified (Henrichs et al., 2013). Females are more susceptible to developing internalizing problems while males are reliably more vulnerable to developing externalizing problems (biological or environmental risk factors) (Zahn - Waxler et al., 2008). However, this link is weak and the fundamental mechanisms undistinguishable (Endendijk et al., 2017).

On the basis of these data, it can be concluded that the maternal thyroid dysfunctions (maternal hypothyroidism) during the gestation may cause several disorders in the neonatal cognitive and social behaviors. These effects might depend on the severity of thyroid disorders, sex type and developmental period. Additional studies are necessary to examine whether the individual variations in $\mathrm{THs}$ trajectories (FT4 and $\mathrm{TSH}$ levels) during the gestation will be a better indicator of neonatal cognitive behavioral disorders than maternal THs levels evaluated at one trimester of pregnancy. In addition, several studies are warranted to examine whether there are sex differences in the interactions between 
the maternal THs trajectories and neonatal cognitive behavioral disorders.

\section{REFERENCES}

[1] Ahmed, O.M., Abd El-Tawab, S.M., Ahmed, R.G., 2010. Effects of experimentally induced maternal hypothyroidism and hyperthyroidism on the development of rat offspring: I- The development of the thyroid hormonesneurotransmitters and adenosinergic system interactions. Int. J. Dev. Neurosci. 28, 437-454.

[2] Ahmed, O.M., Ahmed, R.G., 2012. Hypothyroidism. In A New Look At Hypothyroidism. Dr. D. Springer (Ed.), ISBN: 978-953-51-0020-1), In Tech Open Access Publisher, Chapter 1, pp. 1-20.

[3] Ahmed, O.M., Ahmed, R.G., El-Gareib, A.W., El-Bakry, A.M., Abd El-Tawaba, S.M., 2012. Effects of experimentally induced maternal hypothyroidism and hyperthyroidism on the development of rat offspring: II-The developmental pattern of neurons in relation to oxidative stress and antioxidant defense system. Int. J. Dev. Neurosci. 30, 517-537.

[4] Ahmed, O.M., El-Gareib, A.W., El-bakry, A.M., Abd El-Tawab, S.M., Ahmed, R.G., 2008. Thyroid hormones states and brain development interactions. Int. J. Dev. Neurosci. 26(2), 147-209. Review.

[5] Ahmed, R.G., 2011. Perinatal 2, 3, 7, 8tetrachlorodibenzo-p-dioxin exposure alters developmental neuroendocrine system. Food Chem. Toxicology, 49, 1276-1284.

[6] Ahmed, R.G., 2012a. Maternal-newborn thyroid dysfunction. In the Developmental Neuroendocrinology, pp. 1-369. Ed R.G. Ahmed. Germany: LAP LAMBERT Academic Publishing GmbH \& Co KG.

[7] Ahmed, R.G., 2012b. Maternal-fetal thyroid interactions, Thyroid Hormone, Dr. N.K. Agrawal (Ed.), ISBN: 978-953-51-0678-4, In Tech Open Access Publisher, Chapter 5, pp. 125-156.

[8] Ahmed, R.G., 2013. Early weaning PCB 95 exposure alters the neonatal endocrine system: thyroid adipokine dysfunction. J. Endocrinol. 219 (3), 205-215.

[9] Ahmed, R.G., 2014. Editorial: Do PCBs modify the thyroid-adipokine axis during development? Annals Thyroid Res. 1(1), 11-12.

[10] Ahmed, R.G., 2015a. Chapter 1: Hypothyroidism and brain development. In advances in hypothyroidism treatment.Avid Science Borsigstr.9, 10115 Berlin, Berlin, Germany. Avid Science Publications level 6, Melange Towers, Wing a, Hitec City, Hyderabad, Telangana, India. pp. 1-40.

[11] Ahmed, R.G., 2015b. Hypothyroidism and brain developmental players. Thyroid Research J. 8(2), 1-12.
[12] Ahmed, R.G., 2015c. Editorials and Commentary: Maternofetal thyroid action and brain development. J. of Advances in Biology; 7(1), 1207-1213.

[13] Ahmed, R.G., 2015d.Developmental adipokines and maternal obesity interactions. J. of Advances in Biology; 7(1), 1189-1206.

[14] Ahmed, R.G., 2016a. Maternal bisphenol A alters fetal endocrine system: Thyroid adipokine dysfunction. Food Chem. Toxicology, 95, 168-174.

[15] Ahmed, R.G., 2016b. Gestational dexamethasone alters fetal neuroendocrine axis. Toxicology Letters, 258, 46-54.

[16] Ahmed, R.G., 2016c. Maternal iodine deficiency and brain disorders. Endocrinol. Metab. Syndr.5, 223.http://dx.doi.org/ 10.4172/ 2161-1017.1000223.

[17] Ahmed, R.G., 2016d. Neonatal polychlorinated biphenyls-induced endocrine dysfunction. Ann. Thyroid. Res. 2 (1), 34-35.

[18] Ahmed, R.G.,2017a. Developmental thyroid diseases and GABAergic dysfunction. EC Neurology 8.1, 02-04.

[19] Ahmed, R.G., 2017b. Hyperthyroidism and developmental dysfunction. Arch Med. 9, 4.

[20] Ahmed, R.G.,2017c. Anti-thyroid drugs may be at higher risk for perinatal thyroid disease. EC Pharmacology and Toxicology 4.4, 140-142.

[21] Ahmed, R.G., 2017d. Perinatal hypothyroidism and cytoskeleton dysfunction.Endocrinol MetabSyndr 6, 271.doi:10.4172/2161-1017.10 00271

[22] Ahmed, R.G., 2017e.Developmental thyroid diseases and monoaminergic dysfunction. Advances in Applied Science Research 8(3), 01-10.

[23] Ahmed, R.G., 2017f.Hypothyroidism and brain development.J. Anim Res Nutr.2(2), 13.

[24] Ahmed, R.G., 2017g. Antiepileptic drugs and developmental neuroendocrine dysfunction: Every why has A Wherefore. Arch Med 9(6), 2.

[25] Ahmed, R.G., 2017h. Gestational prooxidantantioxidant imbalance may be at higher risk for postpartum thyroid disease. Endocrinol MetabSyndr 6, 279. doi:10.4172/2161-1017.10 00279.

[26] Ahmed, R.G., 2017i. Synergistic actions of thyroid-adipokines axis during development. EndocrinolMetabSyndr 6, 280.doi:10.4172/21 61-1017.1000280.

[27] Ahmed, R.G., 2017j. Thyroid-insulin dysfunction during development. International Journal of Research Studies in Zoology 3(4), 73-75. DOI: http://dx.doi.org/10.20431/2454941X.0304010.

[28] Ahmed, R.G., 2017k. Developmental thyroid diseases and cholinergic imbalance. International Journal of Research Studies in 
Zoology 3(4), 70-72. DOI: http://dx.doi.org/ 10.20431/2454-941X.0304009.

[29] Ahmed, R.G., 20171. Thyroid diseases and developmental adenosinergic imbalance. Int $\mathbf{J}$ ClinEndocrinol 1(2), 053-055.

[30] Ahmed, R.G., 2017m.Maternal anticancer drugs and fetal neuroendocrine dysfunction in experimental animals. EndocrinolMetabSyndr 6, 281.doi:10.4172/2161-1017.1000281.

[31] Ahmed, R.G., 2017n.Letter: Gestational dexamethasone may be at higher risk for thyroid disease developing peripartum. Open Journal of Biomedical \& Life Sciences (Ojbili) 3(2), 01-06.

[32] Ahmed, R.G., 2017o.Deiodinases and developmental hypothyroidism. EC Nutrition 11.5, 183-185.

[33] Ahmed, R.G., 2017p.Maternofetal thyroid hormones and risk of diabetes. Int. J. of Res. Studies in Medical and Health Sciences 2(10), 18-21.

[34] Ahmed, R.G., 2017r.Association between hypothyroidism and renal dysfunctions. International Journal of Research Studies in Medical and Health Sciences 2(11), 1-4.

[35] Ahmed, R.G., 2017s.Maternal hypothyroidism and lung dysfunction. International Journal of Research Studies in Medical and Health Sciences 2(11), 8-11.

[36] Ahmed, R.G., 2017t.Multidirectional imprinting of maternofetal thyroid hormones. International Journal of Research Studies in Medical and Health Sciences 2(12), 17-21.

[37] Ahmed, R.G., Abdel-Latif, M., Ahmed F., 2015b.Protective effects of GM-CSF in experimental neonatal hypothyroidism. International Immunopharmacology 29, 538543.

[38] Ahmed, R.G., Abdel-Latif, M., Mahdi, E., ElNesr, K., 2015a. Immune stimulation improves endocrine and neural fetal outcomes in a model of maternofetal thyrotoxicosis. Int. Immunopharmacol. 29, 714-721.

[39] Ahmed, R.G., Davis, P.J., Davis, F.B., De Vito, P., Farias, R.N., Luly, P., Pedersen, J.Z., Incerpi, S., 2013b. Nongenomic actions of thyroid hormones: from basic research to clinical applications. An update. Immunology, Endocrine \& Metabolic Agents in Medicinal Chemistry, 13(1), 46-59.

[40] Ahmed, R.G., El-Gareib, A.W. 2014.Lactating PTU exposure: I- Alters thyroid-neural axis in neonatal cerebellum. Eur. J. of Biol. and Medical Sci. Res. 2(1), 1-16.

[41] Ahmed, R.G., El-Gareib, A.W., 2017.Maternal carbamazepine alters fetal neuroendocrinecytokines axis. Toxicology 382, 59-66.

[42] Ahmed, R.G., El-Gareib, A.W., Incerpi, S., 2014. Lactating PTU exposure: II- Alters thyroid-axis and prooxidant-antioxidant balance in neonatal cerebellum. Int. Res. J. of Natural Sciences 2(1), 1-20.

[43] Ahmed, R.G., Incerpi, S., 2013. Gestational doxorubicin alters fetal thyroid-brain axis. Int. J. Devl. Neuroscience 31, 96-104.

[44] Ahmed, R.G., Incerpi, S., Ahmed, F., Gaber, A., 2013a. The developmental and physiological interactions between free radicals and antioxidant: Effect of environmental pollutants. J. of Natural Sci. Res. 3(13), 74-110.

[45] Bornstein, M.H., Hahn, C.S., Suwalsky, J.T., 2013. Physically developed and exploratory young infants contribute to their own long-term academic achievement. Psychol. Sci. 24, 19061917.

[46] Brownlie, E.B., Beitchman, J.H., Escobar, M., Young, A., Atkinson, L., Johnson, C., Douglas, L., 2004.Early language impairment and young adult delinquent and aggressive behavior. J. Abnorm. Child Psychol. 32, 453-467.

[47] Candelotti, E., De Vito, P., Ahmed, R.G., Luly, P., Davis, P.J., Pedersen, J.Z., Lin, H-Y., Incerpi, I., 2015. Thyroid hormones crosstalk with growth factors: Old facts and new hypotheses. Immun., Endoc. \&Metab. Agents in Med. Chem., 15, 71-85.

[48] De Vito, P., Candelotti, E., Ahmed, R.G., Luly, P., Davis, P.J., Incerpi, S., Pedersen, J.Z., 2015.Role of thyroid hormones in insulin resistance and diabetes. Immun., Endoc.\& Metab. Agents in Med. Chem., 15, 86-93.

[49] El-bakry, A.M., El-Ghareeb, A.W., Ahmed, R.G., 2010.Comparative study of the effects of experimentally-induced hypothyroidism and hyperthyroidism in some brain regions in albino rats. Int. J. Dev. Neurosci. 28, 371-389.

[50] El-Ghareeb, A.A., El-Bakry, A.M., Ahmed, R.G., Gaber, A., 2016.Effects of zinc supplementation in neonatal hypothyroidism and cerebellar distortion induced by maternal carbimazole. Asian Journal of Applied Sciences 4(04), 1030-1040.

[51] Endendijk, J.J., Wijnen, H.A.A., Pop, V.J.M., van Baar, A.L., 2017. Maternal thyroid hormone trajectories during pregnancy and child behavioral problems. Hormones \&Behav. 94, 84-92.

[52] Ghassabian, A., Bongers-Schokking, J.J., De Rijke, Y.B., Van Mil, N., Jaddoe, V.W., de Muinck Keizer-Schrama, S.M., Visser, T.J., 2012. Maternal thyroid autoimmunity during pregnancy and the risk of attention deficit/hyperactivity problems in children: The generations R study. Thyroid 22, 178-186.

[53] Ghassabian, A., Bongers-Schokking, J.J., Henrichs, J., Jaddoe, V.W., Visser, T.J., Visser,W., Verhulst, F.C., 2011. Maternal thyroid function during pregnancy and 
behavioral problems in the offspring: The generations R study. Pediatr. Res. 69, 454-459.

[54] Ghassabian, A., Henrichs, J., Tiemeier, H., 2014. Impact of mild thyroid hormone deficiency in pregnancy on cognitive function in children: lessons from the generation $\mathrm{R}$ study. Best Pract. Res. Clin. Endocrinol. Metab. 28, 221-232.

[55] Gigena, N., Alamino, V.A., Montesinos, M.M., Nazar, M., Louzada, R.A., Wajner, S.M., Maia, A.L., Masini-Repiso, A.M., Carvalho, D.P., Cremaschi G.A., Pellizas, C.G., 2017. Dissecting thyroid hormone transport and metabolism in dendritic cells. J. Endocrinology 232, 337-350.

[56] Glinoer, D., De Nayer, P., Robyn, C., Lejeune, B., Kinthaert, J., Meuris, S., 1993.Serum levels of intact human chorionic gonadotropin (HCG) and its free $\alpha$ and $\beta$ subunits, in relation to maternal thyroid stimulation during normal pregnancy. J. Endocrinol. Investig. 16, 881888.

[57] Hagberg, B.S., Miniscalco, C., Gillberg, C., 2010. Clinic attenders with autism or attention deficit/hyperactivity disorder: cognitive profile at school age and its relationship to preschool indicators of language delay. Res. Dev. Disabil. $31,1-8$.

[58] Henrichs, J., Bongers-Schokking, J.J., Schenk, J.J., Ghassabian, A., Schmidt, H.G., Visser, T.J., Visser, W., 2010. Maternal thyroid function during early pregnancy and cognitive functioning in early childhood: The generations R study. J. Clin. Endocrinol.Metab. 95, 42274234.

[59] Henrichs, J., Ghassabian, A., Peeters, R.P., Tiemeier, H., 2013. Maternal hypothyroxinemia and effects on cognitive functioning in childhood: how and why? Clin.Endocrinol. 79, 152-162.

[60] Incerpi, S., Hsieh, M-T., Lin, H-Y., Cheng, GY., De Vito, P., Fiore, A.M., Ahmed, R.G., Salvia, R., Candelotti, E., Leone, S., Luly, P., Pedersen, J.Z., Davis, F.B., Davis, P.J., 2014. Thyroid hormone inhibition in L6 myoblasts of IGF-I-mediated glucose uptake and proliferation: new roles for integrin $\alpha v \beta 3$. Am. J. Physiol. Cell Physiol. 307, C150-C161.
[61] Pop, V.J., Brouwers, E.P., Vader, H.L., Vulsma, T., Van Baar, A.L., De Vijlder, J.J., 2003. Maternal hypothyroxinaemia during early pregnancy and subsequent child development: a 3-year follow-up study. Clin.Endocrinol. 59, 282-288.

[62] Pop, V.J., de Vries, E., van Baar, A.L., Waelkens, J.J., De Rooy, H.A., Horsten,M., Vader, H.L., 1995. Maternal thyroid peroxidase antibodies during pregnancy: a marker of impaired child development? J. Clin. Endocrinol.Metab. 80, 3561-3566.

[63] Pop, V.J., Kuijpens, J.L., van Baar, A.L., Verkerk, G., van Son, M.M., de Vijlder, J.J., Vader, H.L., 1999. Low maternal free thyroxine concentrations during early pregnancy are associated with impaired psychomotor development in infancy. Clin.Endocrinol. 50, 149-155.

[64] Stricker, R.T., Echenard, M., Eberhart, R., Chevailler, M.C., Perez, V., Quinn, F.A., Stricker, R.N., 2007. Evaluation of maternal thyroid function during pregnancy: the importance of using gestational age-specific reference intervals. Eur. J. Endocrinol. 157, 509-514.

[65] Van Herck, S.L.J., Geysens, S., Bald, E., Chwatko, G., Delezie, E., Dianati, E., Ahmed, R.G., Darras, V.M., 2013.Maternal transfer of methimazole and effects on thyroid hormone availability in embryonic tissues.Endocrinol. 218, 105-115.

[66] Van Mil, N.H., Tiemeier, H., BongersSchokking, J.J., Ghassabian, A., Hofman, A., Hooijkaas, H., Visser, W., 2012. Low urinary iodine excretion during early pregnancy is associated with alterations in executive functioning in children. J. Nutr. 142, 21672174.

[67] Zahn-Waxler, C., Shirtcliff, E.A., Marceau, K., 2008. Disorders of childhood and adolescence: gender and psychopathology. Annu. Rev. Clin. Psychol. 4, 275-303.

Citation: Ahmed R.G. Maternal Thyroid Hormones Trajectories and Neonatal Behavioral Disorders. ARC Journal of Diabetes and Endocrinology. 2017; 3(2):18-21. doi:dx.doi.org/10.20431/2455-5983.0302003.

Copyright: (C) 2017 Authors. This is an open-access article distributed under the terms of the Creative Commons Attribution License, which permits unrestricted use, distribution, and reproduction in any medium, provided the original author and source are credited. 